\title{
Effect of generalized ligamentous hyperlaxity related of quality of life in the foot: a case controlled study
}

\author{
Patricia Palomo-López ${ }^{1}$ \\ Ricardo Becerro-de-Bengoa-Vallejo ${ }^{2}$ \\ Marta Elena Losa-Iglesias ${ }^{3}$ \\ (iD) Daniel López-López ${ }^{4}$ \\ (iD) David Rodríguez-Sanz ${ }^{2,5}$ \\ Carlos Romero-Morales ${ }^{5}$ \\ César Calvo-Lobo ${ }^{6}$
}

\begin{abstract}
1. University Center of Plasencia. Universidad de Extremadura, Plasencia, Extremadura, Spain 2. Facultad de Enfermería, Fisioterapia y Podología. Universidad Complutense de Madrid, Madrid, Spain 3. Faculty of Health Sciences. Universidad Rey Juan Carlos, Alcorcón, Spain 4. Research, Health and Podiatry Unit. Department of Health Sciences. Faculty of Nursing and Podiatry. Universidade da Coruña, Ferrol, Spain 5. Faculty of Sport Sciences, European University of Madrid, Villaviciosa de Odón, Madrid, Madrid, Spain
\end{abstract} 6. Department, Faculty of Health Sciences, Universidad de León, Ponferrada, León, Spain

http://dx.doi.org/10.1590/1806-9282.64.09.819

\section{SUMMARY}

Generalized ligamentous hyperlaxity (GLH) has been shown to predispose an individual to a number of orthopaedic conditions. Little is known about how GLH affects people' foot health-related quality of life. This study analyses a sample of people with GLH and people without GLH with normalised reference values of the scores collected with regard to using the Foot Health Status Questionnaire (FSHQ). A total of 100 respondents with mean age of $22.69 \pm 3.78$ years old, who attended a health centre were classified as GLH (n $=50)$ or non-GLH $(n=50)$. The GLH was determined of the patients with and without GLH using assessment with Beighton tool and the scores on the FHSQ were compared. The control group recorded higher scores in the First Section for foot pain, foot function and general foot health, and lower scores in footwear. In the Second Section, they obtained higher scores in social capacity and lower scores in physical activity, vigour and general health. Differences between the two groups were evaluated through a t-test for independent samples, showing statistical significance $(P<0.001)$. This study has detected measurable differences of association between $G L H$ (Beighton score $\geq 4$ ) with impaired quality of life related to foot health.

KEYWORDS: Foot diseases. Musculoskeletal system. Quality of life.

\section{INTRODUCTION}

Generalized ligamentous hyperlaxity (GLH) is more common in individuals who present a musculoskeletal conditions', affecting approximately 5 to $64 \%$ of the population ${ }^{2-4}$ and its prevalence is higher in African ethnic group and females ${ }^{1,3,5}$. Bin Abd Razak et al. ${ }^{1}$ evaluated musculoskeletal problems of patients with GLH compared with subjects without GLH and these patients showed to be 3.35 times more likely to present GLH.

Also, the GLH is characterized by an excessive joint mobility and increased distractibility, beyond the range of motion regarded as normal ${ }^{6}$. In the foot, may be associated with foot pain ${ }^{7}$, ankle sprains ${ }^{8}$, metatarsalgia $^{9}$, pes planus $^{10}$, overpronation ${ }^{11}$, plan- 
tar fasciitis ${ }^{12}$, hallux valgus ${ }^{13}$, tarsal tunne ${ }^{14}$ and ingrown nails ${ }^{15}$.

Thus, this foot disorders may be associated to high cost, and increase economic burden and are one of the leading motivations for physicians care visits regarding the diagnosis and treatment of their foot problems ${ }^{16}$. Also, the multifactorial aetiology is an important factor that might performance restrict, well-being, mobility and autonomy ${ }^{17}$.

Despite this, no studies have been carried out so far to analyse the quality of life related to foot health in population with GLH.

Therefore, this study analyses a sample of people with GLH and people without GLH with normalised reference values of the scores collected with regard to using the Foot Health Status Questionnaire (FSHQ).

\section{MATERIALS AND METHODS}

\section{Design and Sample}

This is a case-controlled study and a convenience sample method was used to select the participants who gave consent and were enrolled into the research. Records of 17 men and 33 women with GLH (mean \pm standard deviation [SD] age, $23.18 \pm 3.02$ years) and compared with 25 male, and 25 female controls (matched for age and gender) without GLH with normalised reference values, who was carried out in a Clinic of Podiatric Medicine and Surgery that provides treatment of diseases and disorders of the foot at University of Extremadura, in the city of Plasencia (Spain) between October 2015 and September 2016.

The main inclusion criteria included subjects under 40 years old, with availability to work full-time during the research, good patience, communication skills, responsibility, no other lower limb injury or surgery over the last six months preceding and no pregnancy. The exclusion criteria included patients with a history of Marfan's syndrome or Ehlers-Danlos, immunocompromised, neurological condition, rheumatoid or systemic conditions, pharmacotherapy, non- or semi-autonomous in daily activities, and unable to understand instructions relating to the study and/or carry them out.

\section{Procedure:}

All examinations, measurements and controls from enrolment using an identical protocol were carried out by the same independent trained clinician. In the first phase, each subject was interviewed and details of medical records were collected including age, gender, previous sporting history, medical history and family history of laxity and musculoskeletal problems were obtained.

In the second phase, anthropometric features, height, weight with the participant barefoot and wearing light clothing was measured, and body mass index (BMI) was calculated from the height (m) and weight $\left(\mathrm{kg}^{2}\right)$, applying Quetelet's equation follow BMI=weight / height ${ }^{2}{ }^{18}$ calculated as weight in kilograms divided by the square of height in meters $\left(\mathrm{kg} / \mathrm{m}^{2}\right)$.

In the third phase, it determined GLH using the modified Beighton 9-point scoring system ${ }^{19}$. This test is validity for diagnosis of GLH showed high Cohen's kappa values (intraobserver: 0.75; interobserver: 0.78) ${ }^{2}$ an overall agreement and a test phase. The subjects were examined following of the five body areas: fifth metacarpophalangeal joint, elbows, knees and trunk. A positive result was recorded if the participant present a cutoff of $\geq 4$ hypermobile joints ${ }^{20,21}$.

Finally, patients were asked to complete the FHSQ 22. This validated instrument on health-related quality of life is intended specifically for the foot ${ }^{23}$. FHSQ, scores provide three separate section scores, with four domains or subscales for each section and two composite scores from 0 being the poorest score to 100 being the best score conditions. First section assesses foot pain, foot function, footwear, general foot health and has demonstrated a high degree of content, criterion, construct validity (Cronbach $\alpha=0.89-0.95$ ) and high retest reliability (intraclass correlation coefficient $=0.74-0.92)^{22}$. Second section looks at general health, physical activity, social capacity and vigour, largely adapted from the Medical Outcomes Study 36Item Short-Form Health ${ }^{23}$, which has demonstrated validated ${ }^{24}$ foot function, footwear and general foot health. RESULTS The MID for the VAS using the anchor-based approach was $-8 \mathrm{~mm}$ (95\% CI: -12 to -4 . Third section focuses on socio-demographic data such as age, gender and medical record.

\section{Ethical considerations}

This research was approved by the Bioethics and Biosafety Committee of the University of Extremadura (Spain), record number: 85/2016. All participants provided informed written consent before being included, and the ethical standards in human experimentation contained in the WMA Declaration of Helsinki, the Council of Europe Convention on Human Rights and Biomedicine, the UNESCO Universal Dec- 
laration on the Human Genome and Human Rights and those of the relevant national agencies and institutions were observed at all times.

\section{Sample size}

Having established a minimal difference score of at least 21 (as clinically relevant) among the groups under study in the FHSQ, and considering that the standard deviation on that scale for people is around $29^{25,26}$, for a bilateral hypothesis, an alpha risk of $5 \%$ and a statistical power of $80 \%$, at least 47 cases must be studied in each group with a total population of 94 people. Controls were matched to cases according to age and gender.

\section{Statistical analysis}

Population demographic data including age, height, weight, BMI, marital status, level of education and professional activity, and independent variables were summarized as mean and standard deviation (SD), maximum and minimum values and compared between people with and without GLH.

All variables were examined for normality of distribution using the Kolmogorov-Smirnov test, and data were considered normally distributed if $p>$ 0.05. Independent Student t-tests were performed to find if differences are statistically significant when showing a normal distribution. Measurements which were not normally distributed were tested using non-parametric Mann-Whitney $U$ test to examine differences between the two groups.

The Foot Health Status Questionnaire Version 1.03 was used to obtain quality of life scores related to foot health. In all of the analyses, statistical significance was established with a $p$-value $<0.01$ with a confidence interval of $99 \%$. All the analyses were performed with commercially available software (SPSS 19.0, Chicago, IL, USA).

\section{RESULTS}

All the variables showed a normal distribution $(\mathrm{P}<0.05)$ except for $\mathrm{BMI}$ and Vigour $(\mathrm{P}>0.05)$. Mann-Whitney U tests were used to examine differences between two groups, except for BMI and vigour where independent $t$ student test were applied.

A total of one hundred individuals between 18 and 35 years of age, the mean age being $22.69 \pm 3.78$ years old, completed the research course. Table 1 shows the sociodemographic characteristics of the participants showing according to GLH. Only a significant difference at Beighton 9-point scoring were found $(\mathrm{P}<0.01)$.

Furthermore, as part of their clinical evaluation, fifty subjects met the criteria for GLH and had a Beighton mean score recorded of $6.98 \pm 1.635$, and the results of a comparison between FHSQ scores of the cases and control groups are shown in table 2 . These scores were higher for the control group, in the First section for the foot pain, foot function and general foot health and lower scores in footwear. In the Second section, they obtained higher scores in social capacity and lower scores in physical activity, vigour and general health.

The differences between groups were statistically significant $(p=0.001)$ only for footwear (Figure 1): There were no significant differences for dimensions in the questionnaire that assessed foot pain, foot function, general foot health, general health, physical activity, social capacity and vigour $(\mathrm{P}>0.01)$.

\section{DISCUSSION}

Persons with or without GLH require a complete musculoskeletal examination that should include a specific assessment of feet because of factors present in the foot that allow the detection of this problem ${ }^{27}$.

Thus, in this study, we analyse a sample of people with GLH and people without GLH with normalised

TABLE 1 - SOCIO-DEMOGRAPHIC AND CLINICAL CHARACTERISTICS OF THE SAMPLE POPULATION.

\begin{tabular}{|c|c|c|c|c|}
\hline & $\begin{array}{l}\text { Total Group } \\
\text { Mean } \pm \text { SD } \\
\text { Range } \\
\mathrm{N}=100\end{array}$ & $\begin{array}{l}\text { GLH } \\
\text { Mean (SD) } \\
\text { Range } \\
\mathrm{N}=50\end{array}$ & $\begin{array}{l}\text { Non-GLH } \\
\text { Mean (SD) } \\
\text { Range } \\
\mathrm{N}=50\end{array}$ & $\begin{array}{l}P \\
\text { Value }\end{array}$ \\
\hline Age, years & $\begin{array}{l}22.87 \pm 3.16 \\
(18-35)\end{array}$ & $\begin{array}{l}23.18 \pm 3.01 \\
(18-35)\end{array}$ & $\begin{array}{l}22.56 \pm 3.31 \\
(18-35)\end{array}$ & 0.191 \\
\hline Weight (kg) & $\begin{array}{l}68.71 \pm 12.32 \\
(47-105)\end{array}$ & $\begin{array}{l}64.86 \pm 11.69 \\
(48-95)\end{array}$ & $\begin{array}{l}68.56 \pm 12.77 \\
(47-105)\end{array}$ & 0.129 \\
\hline Height (cm) & $\begin{array}{l}160.00 \pm 0.16 \\
(150-193)\end{array}$ & $\begin{array}{l}168.26 \pm 8.32 \\
(156-186)\end{array}$ & $\begin{array}{l}170.04 \pm 1.03 \\
(150-193)\end{array}$ & 0.394 \\
\hline $\mathrm{BMI}(\mathrm{kg} / \mathrm{m} 2)$ & $\begin{array}{l}23.19 \pm 3.03 \\
(17.68-31.86)\end{array}$ & $\begin{array}{l}22.79 \pm 2.99 \\
(18.50-31.86)\end{array}$ & $\begin{array}{l}23.58 \pm 3.05 \\
(17.69-30.79)\end{array}$ & 0.135 \\
\hline $\begin{array}{l}\text { Beighton } \\
\text { 9-point scoring }\end{array}$ & $\begin{array}{l}3.91 \pm 3.36 \\
(0.00-9.00)\end{array}$ & $\begin{array}{l}6.98 \pm 1.63 \\
(4.00-9.00)\end{array}$ & $\begin{array}{l}0.84 \pm 0,95 \\
(0.00-3.00)\end{array}$ & $<0.001$ \\
\hline Marital status & $\begin{array}{l}1.39 \pm 1.11 \\
(1-5)\end{array}$ & $\begin{array}{l}1.58 \pm 1.31 \\
(1-5)\end{array}$ & $\begin{array}{l}1.20 \pm 0.81 \\
(1-5)\end{array}$ & 0.066 \\
\hline $\begin{array}{l}\text { Level of edu- } \\
\text { cation }\end{array}$ & $\begin{array}{l}3.35 \pm 0.63 \\
(2-5)\end{array}$ & $\begin{array}{l}3.40 \pm 0.67 \\
(2-5)\end{array}$ & $\begin{array}{l}3.30 \pm 0.58 \\
(2-5)\end{array}$ & 0.386 \\
\hline $\begin{array}{l}\text { Professional } \\
\text { activity }\end{array}$ & $\begin{array}{l}1.14 \pm 0.493 \\
(1-3)\end{array}$ & $\begin{array}{l}1.66 \pm 0.479 \\
(1-3)\end{array}$ & $\begin{array}{l}1.04 \pm 0.28 \\
(1-3)\end{array}$ & 0.029 \\
\hline
\end{tabular}

Abbreviations: BMI, body mass index; SD, standard deviation; GLH, generalized ligamentous hyperlaxity. In all the analyses, $\mathrm{P}<.01$ (with a $99 \%$ confidence interval) was considered statistically significant. 
reference values of the scores collected with regard to using the FSHQ. We found, for the first time in the control group that recorded higher scores in the First Section for foot pain, foot function and general foot health and lower scores in footwear that in the group of GLH.

These results suggest that GLH is related with more foot pain, greater restrictions in terms of footwear and they consider that their feet are in a worse state of foot health and may favour the presence of a number of foot pathologies ${ }^{28}$ however, its association with musculoskeletal pain remains controversial. There is lack of data from developing countries like India. This study aimed to look at the prevalence of musculoskeletal complaints and hypermobility in Indian school children. METHODS This was a cross-sectional, school-based study. Initially, a questionnaire regarding musculoskeletal pain was filled in by the schoolchildren (or their parents.

Also, in the Second Section in the control group, they obtained higher scores in social capacity and lower scores in physical activity, vigour and general health and this findings are different from other studies linking GLH to poor health-related quality of life ${ }^{29,30}$ to compare these with other chronic paediatric conditions and to determine whether symptoms experienced by children with JHS can predict their HRQOL. METHODS Eighty-nine children with JHS and one of their parents completed

TABLE 2 - COMPARISONS OF FHSQ SCORES FOR THE CASE AND CONTROL GROUPS.

\begin{tabular}{|c|c|c|c|c|}
\hline & $\begin{array}{l}\text { Total Group } \\
\text { Mean } \pm S D \\
\text { Range } \\
N=100\end{array}$ & $\begin{array}{l}\text { GLH } \\
\text { Mean (SD) } \\
\text { Range } \\
\mathrm{N}=50\end{array}$ & $\begin{array}{l}\text { Non-GLH } \\
\text { Mean (SD) } \\
\text { Range } \\
\mathrm{N}=50\end{array}$ & $\begin{array}{l}\text { P } \\
\text { Value }\end{array}$ \\
\hline Foot Pain & $\begin{array}{l}81.86 \pm 15.51 \\
(40.62-100)\end{array}$ & $\begin{array}{l}81.67 \pm 17.48 \\
(40.62-100)\end{array}$ & $\begin{array}{l}82.05 \pm 13.43 \\
(41.25-100)\end{array}$ & 0.539 \\
\hline Foot Function & $\begin{array}{l}89.63 \pm 15.03 \\
(43,75-100)\end{array}$ & $\begin{array}{l}89.25 \pm 15.42 \\
(43.75-100)\end{array}$ & $\begin{array}{l}90.00 \pm 14.78 \\
(25-100)\end{array}$ & 0.729 \\
\hline Footwear & $\begin{array}{l}67.42 \pm 29.61 \\
(0-100)\end{array}$ & $\begin{array}{l}74.67 \pm 30.54 \\
(0-100)\end{array}$ & $\begin{array}{l}60.17 \pm 27.06 \\
(0-100)\end{array}$ & 0.002 \\
\hline $\begin{array}{l}\text { General Foot } \\
\text { Health }\end{array}$ & $\begin{array}{l}65.87 \pm 21.43 \\
(0-100)\end{array}$ & $\begin{array}{l}65.10 \pm 25.00 \\
(0-100)\end{array}$ & $\begin{array}{l}66.65 \pm 17.38 \\
(10-100)\end{array}$ & 0.912 \\
\hline General Health & $\begin{array}{l}75.50 \pm 23.19 \\
(0-100)\end{array}$ & $\begin{array}{l}77.00 \pm 22.24 \\
(0-100)\end{array}$ & $\begin{array}{l}74.00 \pm 24.24 \\
(0-100)\end{array}$ & 0.443 \\
\hline $\begin{array}{l}\text { Physical Ac- } \\
\text { tivity }\end{array}$ & $\begin{array}{l}93.28 \pm 9.58 \\
(61.11-100)\end{array}$ & $\begin{array}{l}94.44 \pm 8.02 \\
(61.11-100)\end{array}$ & $\begin{array}{l}92.11 \pm 10.89 \\
(61.11-100)\end{array}$ & 0.379 \\
\hline Social Capacity & $\begin{array}{l}86.63 \pm 20.2 \\
(0-100)\end{array}$ & $\begin{array}{l}86.25 \pm 23.72 \\
(0-100)\end{array}$ & $\begin{array}{l}87.00 \pm 16.16 \\
(50-100)\end{array}$ & 0.432 \\
\hline Vigour & $\begin{array}{l}63.81 \pm 16.93 \\
(12.5-100)\end{array}$ & $\begin{array}{l}64.00 \pm 17.66 \\
(12.50-100)\end{array}$ & $\begin{array}{l}63.62 \pm 16.35 \\
(25-100)\end{array}$ & 0.922 \\
\hline
\end{tabular}

Abbreviations: FHSQ, Foot Health Status Questionnaire; SD, standard deviation; GLH, generalized ligamentous hyperlaxity. In all the analyses, P <.01 (with a 99\% confidence interval) was considered statistically significant.

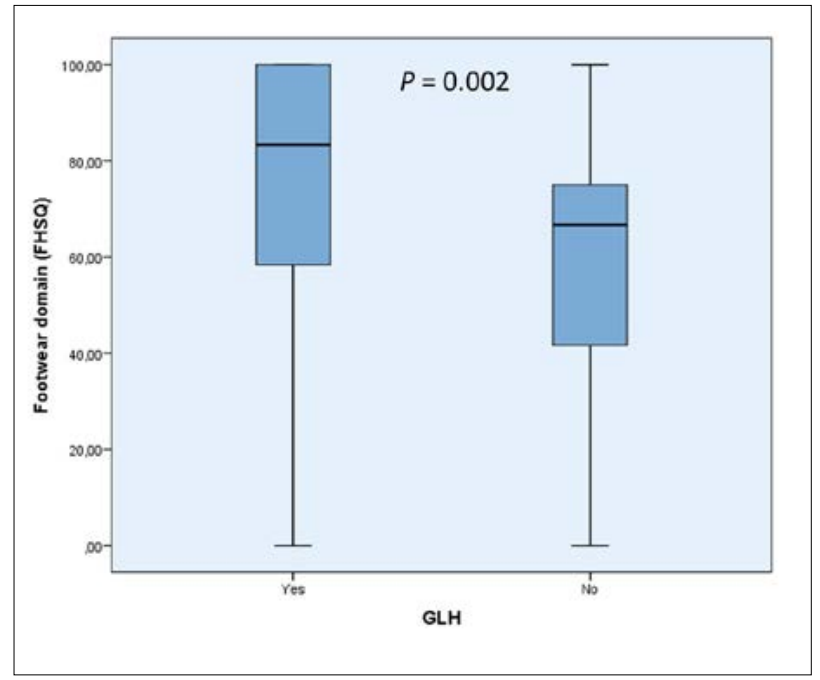

FIGURE 1. Box-plot to illustrate the footwear domain differences of the FHSQ between subjects with and without GLH. Abbreviations; FHSQ, Foot Health Status Questionnaire (FHSQ); GLH, Generalized ligamentous hyperlaxity.

the Pediatric Quality of Life Inventory 4.0 Generic Core Scale, the Multidimensional Fatigue Scale and the Pediatric Pain Questionnaire. Anthropometric measures and reported symptoms were recorded. Child-reported HRQOL scores were compared with parent report, and both child- and parent-reported HRQOL scores of children with JHS were compared with those of children with other chronic conditions. Stepwise multiple regression was undertaken to determine whether any combination of measures could predict HRQOL. RESULTS Parent- and child-reported HRQOL scores were strongly correlated $(\mathrm{r}=0.6-0.84$, all $\mathrm{P}<0.001$.

We acknowledge that the present research has limitations. Notably, this study included a larger number of participants from various countries; random sample size would be beneficial to improve the strength of the study. In addition, even though sample size calculation was carried out, the consecutive sampling bias should be considered and a simple randomization sampling process could be more adequate for future studies. Finally, it should be determined other variables such as shoe wearing or socioeconomic status on impact of GLH related of quality of life. This highlights the need for regular foot care and monitoring in people with GLH.

\section{CONCLUSIONS}

This research identified measurable differences of association between GLH (Beighton score $\geq 4$ ) with 
impaired quality of life related to foot health. Our findings suggest a negative impact on the quality of life related to foot health which appears to be associated with the GLH.

\section{ACKNOWLEDGEMENTS}

We would like to thank the staff and patients of Podiatric Medicine and Surgery Clinic, University of Extremadura, Plasencia, Spain.

\section{RESUMO}

A hiperlaxia ligamentosa generalizada (HLG) demonstrou predispor um indivíduo a várias condições ortopédicas. Pouco se sabe sobre como a HLG afeta a qualidade de vida relacionada à saúde do pé das pessoas. Este estudo analisa uma amostra de pessoas com HLG e pessoas sem HLG com valores de referência normalizados das pontuações coletadas no que diz respeito ao Foot Health Status Questionnaire (FSHQ). Um total de 100 informantes com média de idade de 22,69 \pm 3,78 anos que eram atendidos em um centro de saúde foi classificado como HLG $(n=50)$ ou não HLG $(n=50)$. A HLG foi determinada com os pacientes com e sem HLG usando a ferramenta Beighton e os escores na FHSQ foram comparados. O grupo de controle registrou pontuações mais altas na primeira seção para a dor no pé, função do pé e saúde geral do pé, e menores pontuações no calçado. Na segunda seção obtiveram maiores escores em capacidade social e menores escores em atividade física, vigor e saúde geral. As diferenças entre os dois grupos foram avaliadas por meio de um teste $t$ para amostras independentes, mostrando significância estatística $(P<0,001)$. Este estudo detectou diferenças mensuráveis de associação entre HLG (pontuação de Beighton $\geq 4$ ) com deterioração da qualidade de vida relacionada à saúde dos pés.

PALAVRAS-CHAVE: Doenças dos pés. Sistema musculoesquelético. Qualidade de vida.

\section{REFERENCES}

1. Bin Abd Razak HR, Bin Ali N, Howe TS. Generalized ligamentous laxity may be a predisposing factor for musculoskeletal injuries. I Sci Med Sport. 2014;17(5):474-8.

2. Juul-Kristensen B, Røgind $H$, Jensen DV, Remvig L. Inter-examiner reproducibility of tests and criteria for generalized joint hypermobility and benign joint hypermobility syndrome. Rheumatology (Oxford). 2007;46(12):1835-41.

3. Remvig L, Jensen DV, Ward RC. Epidemiology of general joint hypermobility and basis for the proposed criteria for benign joint hypermobility syndrome: review of the literature. J Rheumatol. 2007;34(4):804-9.

4. Lamari NM, Chueire AG, Cordeiro JA. Analysis of joint mobility patterns among preschool children. Sao Paulo Med J. 2005;123(3):119-23.

5. Chahal J, Leiter J, McKee MD, Whelan DB. Generalized ligamentous laxity as a predisposing factor for primary traumatic anterior shoulder dislocation. J Shoulder Elb Surg. 2010;19(8):1238-42.

6. Smits-Engelsman B, Klerks M, Kirby A. Beighton Score: a valid measure for generalized hypermobility in children. J Pediatr. 2011;158(1):119-23.

7. Vega J, Peña F, Golanó P. Minor or occult ankle instability as a cause of anterolateral pain after ankle sprain. Knee Surg Sports Traumatol Arthrosc. 2016;24(4):1116-23.

8. Beynnon BD, Murphy DF, Alosa DM. Predictive factors for lateral ankle sprains: a literature review. J Athl Train. 2002;37(4):376-80.

9. Greisberg J, Sperber L, Prince DE. Mobility of the first ray in various foot disorders. Foot Ankle Int. 2012;33(1):44-9.

10. Agnew P. Evaluation of the child with ligamentous laxity. Clin Podiatr Med Surg. 1997;14(1):117-30.

11. Ferrari J, Parslow C, Lim E, Hayward A. Joint hypermobility: the use of a new assessment tool to measure lower limb hypermobility. Clin Exp Rheumatol. 2005;23(3):413-20.

12. Hudson N, Starr MR, Esdaile JM, Fitzcharles MA. Diagnostic associations with hypermobility in rheumatology patients. $\mathrm{Br}$ ) Rheumatol. 1995;34(12):1157-61.

13. King DM, Toolan BC. Associated deformities and hypermobility in hallux valgus: an investigation with weightbearing radiographs. Foot Ankle Int. 2004:25(4):251-5.

14. Pisani G, Pisani PC, Parino E. Sinus tarsi syndrome and subtalar joint instability. Clin Podiatr Med Surg. 2005;22(1):63-77.

15. Erdogan FG, Tufan A, Guven M, Goker B, Gurler A. Association of hypermobility and ingrown nails. Clin Rheumatol. 2012;31(9):1319-22.

16. Papaliodis DN, Vanushkina MA, Richardson NG, DiPreta JA. The foot and ankle examination. Med Clin North Am. 2014;98(2):181-204.

17. Rodríguez-Sanz D, Tovaruela-Carrión N, López-López D, Palomo-López
P, Romero-Morales C, Navarro-Flores E, et al. Foot disorders in the elderly: a mini-review. Dis Mon. 2018;64(3):64-91.

18. Centers of Disease Control. Body mass index: considerations for practitioners. CDC [Internet]. 2011 [cited 2016 Dec 16];4. Available from: http://scholar.google.com/scholar?hl=en\&btnG=Search\&q=intitle:Body+Mass+Index+:+Considerations+for+Practitioners\#3\%5Cnhttp://scholar.google.com/scholar?hl=en\&btnG=Search\&q=intitle:Body+mass+index:+Considerations+for+practitioners $\% 233$

19. Beighton P, Grahame R, Bird H. Clinical features of hypermobility: locomotor system and extra-articular. In: Hypermobility of joints [Internet]. London: Springer London; 1999. p.53-80. Available from: http://link. springer.com/10.1007/978-1-4471-3633-0_5

20. Seçkin U, Tur BS, Yılmaz O, Yağcı I, Bodur $H$, Arasil T. The prevalence of joint hypermobility among high school students. Rheumatol Int. 2005;25(4):260-3.

21. Grahame R, Hakim AJ. Hypermobility. Curr Opin Rheumatol. 2008;20(1):106-10.

22. Bennett PJ, Patterson C, Wearing S, Baglioni T. Development and validation of a questionnaire designed to measure foot-health status. J Am Podiatr Med Assoc. 1998;88(9):419-28.

23. Bennett PJ, Patterson C, Dunne MP. Health-related quality of life following podiatric surgery. J Am Podiatr Med Assoc. 2001;91(4):164-73.

24. Landorf KB, Radford JA, Hudson S. Minimal Important Difference (MID) of two commonly used outcome measures for foot problems. J Foot Ankle Res. 2010;3:7.

25. Irving DB, Cook JL, Young MA, Menz HB. Impact of chronic plantar heel pain on health-related quality of life. J Am Podiatr Med Assoc. 2008;98(4):283-9.

26. Cuesta-Vargas A, Bennett $P$, Jimenez-Cebrian AM, Labajos-Manzanares MT. The psychometric properties of the Spanish version of the Foot Health Status Questionnaire. Qual Life Res. 2013;22(7):1739-43.

27. Benhamú-Benhamú S, Domínguez-Maldonado G, García-De-La-Peña R, Jiménez-Cristino MD, Gijon-Nogueron G. Clinical signs in the foot that are predictors of ligamentous laxity in the adult population. J Tissue Viability. 2015;24(4):153-64.

28. Abujam B, Aggarwal A. Hypermobility is related with musculoskeletal pain in Indian school-children. Clin Exp Rheumatol. 2014;32(4):610-3.

29. Pacey V, Tofts L, Adams RD, Munns CF, Nicholson LL. Quality of life prediction in children with joint hypermobility syndrome. J Paediatr Child Health. 2015;51(7):689-95.

30. Terry RH, Palmer ST, Rimes KA, Clark C), Simmonds JV, Horwood JP. Living with joint hypermobility syndrome: patient experiences of diagnosis, referral and self-care. Fam Pract. 2015;32(3):354-8. 